\title{
EVALUATION THE EFFICIENCY OF SOME INSECTICIDES AND MINERAL OILS AGAINST THE WHEAT APHID ON TURFGRASS
}

MANSOUR, A. M. A.

Plant Protection Research Institute, ARC, Dokki, Giza

(Manuscript received 8 August 2008)

\begin{abstract}
The field experiment was carried out in a turfgrass farm located at Menofia Governorate during 2006 year. Six insecticides and three mineral oils were evaluated for their efficacy as aphicides on wheat aphid insect, Schizaphis graminum (Rondani) infesting Seashore paspalum, cv Sea Dwarf turfgrass. All treatments gave satisfactory results, whereas Malathion 57\% EC, Reldan 40\% EC, Deltan 40\% EC and Sumithion 50\% EC gave highly superior effect. The residual toxicity of these insecticides were $97.7,97.7,97.4$ and $92.4 \%$, respectively. Folk oil $2 \%$ EC gave the least aphicidal effect with a residual toxicity of $63.68 \%$.
\end{abstract}

\section{INTRODUCTION}

Turfgrass is the most widely grown ornamental crop in Egypt, (El-Kiey, 1988). It is grown under many environmental conditions and for different uses, such as sports complexes, parked recreation fields, sod production, golf courses and homeowner lawn care. In urban areas, turfgrass covers thousands of feddans and will likely increase as urban sprawl continues to expand into agricultural lands. The contribution of turfgrasses to erosion control on roadsides, lawns and playgrounds can be measured in thousand of feddans of land saved each year.

Without some maintenance, including pest control, those areas would quickly become damaged and overgrown with undesirable vegetation.

The wheat aphid insect, Schizaphis graminum (Rondani) is one of the most serious insect pests infesting turfgrass in Egypt. It causes several damage to the plants if not controlled (Nuessly \& Nagate, 2005). Aphids suck the sap from blades and the damage appears as pale areas often with yellow streaking.

Chemical control may be an effective method against this insect, therefore the present study aims to evalute the insecticidal efficiency of some insecticides and mineral oils against such pest insect.

\section{MATERIALS AND METHODS}

The studies were carried out in private farms of turfgrass, at Menofia Governorate during May 2006. Seashore paspalum, cv Sea Dwarf turfgrass treated 
with six commonly available insecticides and three mineral oils to control the wheat aphid insect, Schizaphis graminum (Rondani).

The Insecticides used and their rates per feddan: Malathion 57\% EC at 1.5 Lit., Reldan 40\% EC at 2 Lit., Deltan 40\% EC at 0.4 Lit., Actellic 50\% EC at 1.2 Lit., Sumithion $50 \%$ EC at $1 \mathrm{Lit}$. and Acephate $75 \%$ SP at $1 \mathrm{Kg}$.

The mineral oils: KZ-oil 1.5\% EC, Folk-oil 2\% EC and Royal-oil 1.5\% EC at rates 1.5 Lit./feddan.

The site of the experimental area was divided into plots of $1 / 100$ feddan for each. Each treatment or control (treated with water only) was replicated three times (3 plots). All treatments were arranged in a complete randomized block design. The conventional agricultural practices were applied regularly. An ordinary knapsack sprayer of 20 Liters capacity with a bent down nozzle was used. Sample size was the number of alive aphides found on area $50 / 100 / 20 \mathrm{~cm} /$ plot. The number of aphid was recorded before treatment and 2, 5, 8, 11 and 14 days after treatment. The reduction percentage of population density and the residual activity as a result of insecticide application was estimated using Abbott (1925) formula and Henderson and Tilton (1955) equation.

\section{RESULTS AND DISCUSSION}

The data presented in Tables (1\&2) indicated obviously the effectiveness of the used insecticides and mineral oils on the population density reduction of the wheat aphid insect, Schizaphis graminum (Rondani) on sea Dwarf turfgrass. The percentage of reduction varied considerably due to the type of toxicant and may be to differences in the additives in the formulation (Shetlar, 2003). The data also showed that, the tested insecticides and mineral oils varied significantly in their efficiencies against the wheat aphid.

The tested insecticides could be arranged according to their means of population and reduction percentage after 14 days of spraying into two groups.

\section{The first group includes}

Malathion 57\% EC, Deltan 40\% EC, Reldan 40\% EC and Sumithion 50\% EC, respectively. This group proved to be highly efficient aphicides, whereas percentages of reduction after 14 days from spraying were 97.4, 96.0, 95.8 and 83.6\%, respectively.

\section{The second group includes}

Acephat $75 \%$ SP and Actellic 50\% EC, respectively. This group occupied an intermediate position, whereas the reduction percentages were 78.4 and $68.1 \%$, respectively. 
Also, results in the same tables showed that the tested mineral oils differed in their efficiency for aphid control. The means of aphid populations and reduction percentage after 14 days of spraying could be arranged as follows:

Table 1. Efficacy of insecticides and mineral oils against the wheat aphid insect, Schizaphis graminum (Rondani) on Seashore paspalum, cv Sea Dwarf turfgrass.

\begin{tabular}{|c|c|c|c|c|c|c|c|c|}
\hline \multirow[b]{2}{*}{ Treatments } & \multirow{2}{*}{$\begin{array}{c}\text { Rate of } \\
\text { application } \\
\text { feddan }\end{array}$} & \multirow{2}{*}{$\begin{array}{l}\text { No. of } \\
\text { aphids } \\
\text { (pre- } \\
\text { treatment) }\end{array}$} & \multicolumn{5}{|c|}{ Mean No. aphids (post-treatment) } & \multirow{2}{*}{$\begin{array}{l}\text { Overall } \\
\text { mean }\end{array}$} \\
\hline & & & 2 days & 5 days & 8 days & $\begin{array}{c}11 \\
\text { days }\end{array}$ & $\begin{array}{c}14 \\
\text { days }\end{array}$ & \\
\hline Malathion & 1.5 Lit. & 1728.3 & 18.3 & 36.0 & 38.0 & 39.0 & 44.7 & 35.20 \\
\hline Actellic & 1.2 Lit. & 1707.3 & 253.7 & 136.3 & 512.0 & 519.0 & 548.3 & 393.86 \\
\hline Sumithion & 1 Lit. & 1739.0 & 88.7 & 53.3 & 49.7 & 136.3 & 286.7 & 122.94 \\
\hline Acephate & $1 \mathrm{Kg}$ & 1726.3 & 136.7 & 128.3 & 232.3 & 350.0 & 374.3 & 244.32 \\
\hline Reldan & 0.2 Lit. & 1737.3 & 38.3 & 32.3 & 27.0 & 31.0 & 72.7 & 40.26 \\
\hline Deltan & 0.4 Lit. & 1706.0 & 34.0 & 19.7 & 43.0 & 51.3 & 67.7 & 43.14 \\
\hline KZ-oil & 1.5 Lit. & 1708.0 & 511.3 & 493.0 & 503.3 & 517.7 & 611.7 & 539.40 \\
\hline Folk-oil & 1.5 Lit. & 1684.0 & 916.3 & 678.3 & 571.3 & 589.3 & 620.7 & 675.12 \\
\hline Royal-oil & 1.5 Lit. & 1728.3 & 369.0 & 321.6 & 227.7 & 157.3 & 200.7 & 255.26 \\
\hline Control & - & 1711.3 & 1735.0 & 1728.3 & 1713.0 & 1708.0 & 1721.0 & 1721.0 \\
\hline
\end{tabular}

LSD $_{0.05}$ treatment: 4.26

LSD $_{0.01}$ treatment: 6.12
LSD $_{0.05}$ day: 3.54

$\mathrm{LSD}_{0.01}$ day: 5.56 
Table 2. Reduction percentages and mean residual effect of different insecticides and mineral oils on the wheat aphid insect, Schizaphis graminum (Rondani) on Seashore paspalum, cv Sea Dwarf turfgrass.

\begin{tabular}{|c|c|c|c|c|c|c|c|}
\hline \multirow{2}{*}{ Treatments } & \multirow{2}{*}{$\begin{array}{c}\text { Rate of } \\
\text { application } \\
\text { Feddan }\end{array}$} & \multicolumn{5}{|c|}{ \% Reduction } & \multirow{2}{*}{$\begin{array}{l}\text { Mean } \\
\text { residual } \\
\text { effect\% }\end{array}$} \\
\hline & & 2 days & 5 days & 8 days & 11 days & 14 days & \\
\hline Malathion & 1.5 Lit. & 98.96 & 97.94 & 97.80 & 97.74 & 97.40 & 97.72 \\
\hline Actellic & 1.2 Lit. & 85.30 & 92.10 & 70.00 & 69.20 & 68.10 & 74.85 \\
\hline Sumithion & 1 Lit. & 95.00 & 96.90 & 97.15 & 92.10 & 83.60 & 92.44 \\
\hline Acephate & $1 \mathrm{Kg}$ & 92.20 & 92.60 & 87.00 & 79.70 & 78.40 & 84.43 \\
\hline Reldan & $\begin{array}{l}0.2 \text { Lit./ } \\
\text { Feddan }\end{array}$ & 97.80 & 98.20 & 98.40 & 98.20 & 95.80 & 97.70 \\
\hline Deltan & 0.4 Lit. & 98.03 & 98.90 & 97.50 & 97.00 & 96.00 & 97.40 \\
\hline KZ-oil & 1.5 Lit. & 70.50 & 71.00 & 71.00 & 69.60 & 61.00 & 68.15 \\
\hline Folk-oil & 1.5 Lit. & 46.00 & 60.40 & 66.10 & 64.90 & 63.30 & 63.68 \\
\hline Royal-oil & 1.5 Lit. & 78.90 & 81.60 & 86.80 & 91.00 & 88.50 & 86.98 \\
\hline
\end{tabular}

Royal-oil 1.5\% EC (88.5\%), KZ-oil 1.5\% EC (61.0\%) and Folk-oil 2\% EC (63.3\%), respectively.

With regard to the mean residual effect of the tested compounds, could be arranged in the following descending order, Malathion, Reldan, Deltan, Sumithion, Royal-oil, Acephate, Actellic , KZ-oil and Folk-oil. The corresponding values of the mean residual toxicity were $97.72,97.7,97.4,92.44,86.98,84.43,74.85,68.15$ and $63.68 \%$, respectively. The previous data show that Malathion was the most potent aphicides against, S. graminum among all compounds tested in this experiment, on the contrary, Folk-oil was the least one. Royal-oil proved to be the most effective mineral oils and more effect than some insecticides (Acephat and Actellic). These oils were more safed than insecticides on the environments and gave significant efficacy in reducing the aphid infestation in turfgrass.

Significant difference was observed between all compound treatments and untreated check was shown in Table (1).

The efficiency of aphicides on $S$. graminum under the field conditions was reported by many authors, Miller and Smith (2001), Kovach et al. (2003), Shetlar 
(2003), Nuessly et al. (2004) and Nuessly \& Nagate (2005). They observed that chemical control is often needed, when wheat aphid population are causing noticeable damage to trufgrass. Several systemic pyrethroid, organophosphorus and carbamate insecticides are effective against this aphid perl on turfgrass.

Baxendale and Johson (1998) reported that, summer oil or horticultural spray oil has proven very effective in reducing population of the greenbugs on turfgrass. Similar results were obtained by Hays et al. (1999).

\section{REFERENCES}

1. Abbott, W. S. 1925. A method of computing the effectiveness of an insecticide. J. Econ. Entomol., 18: 265-267.

2. Baxendale, R. W. and W. T. Johson. 1998. Evaluation of summer oil spray on amenity palnts. J. Arboric., 14: 220-225.

3. El-Kiey, T. 1988. Lawns and ground cover. Fgr. Aleslam Prin. \& Pub. Companies Alex., 177 Pp.

4. Hays, D. B., D. R. Porter, J. A. Webster and B. F. Carver. 1999. Feeding behavior of biotypes $\mathrm{E}$ and $\mathrm{H}$ greenbug (Homoptera : Aphididae) on previously infested nearisolines of barley. J. Econ. Entomol., 62: 776-779.

5. Henderson, C. F. and E. W. Tilton. 1955. Tests with acaricides against the brown wheat mite. J. Econ Entomol., 48 : 157-161.

6. Kovach, J., C. Young and S. Prochaska. 2003. Pesticide use on turfgrass in Ohio 2001. Special Circular 191. Ohio Agric. Res. and Develop. Center, August 2003.

7. Miller, R. L. and A. W. Smith. 2001. The greenbug aphid and its control. Ohio State University Fact Sheet. Hort. and Crop Sci. HYG-2030 : 88.

8. Nuessly, G. S. and R. T. Nagata. 2005. Evaluation of insecticides for control of greenbug on seashore paspalum, 2004. Entomol. Soc. America, 30 June 2005.

9. Nuessly, G. S., R. T. Nagata, R. L. Beiriger, B. T. Scully and S. Halbert. 2004. Aphid damaging seashore paspalum. Florida Turf Digest., Jan./Feb.: 24.

10. Shetlar, D. J. 2003. Aphids on trees and shrub. Ohio State University extension Fact Sheet. Department of Horticulture and Crop Science, HYG-2030:88. 


\section{تقييم كفاعة بعض المبيدات الحشرية والزيوت المعدنية ضد من النجيليات \\ علي المسطحات الخضراء \\ أحمد عبد الحكيم منصور \\ معه بحوث وقاية النباتات- مركز البحوث النزاعية- اللقي- جيزة .}

أجريت تجربـة حقليـة في مزرعـة مسطحات خضـراء بمحافظـة المنوفيـة لتقيجم فعاليـة وكفاءة

بعض المبيدات الحشرية والزيوت المعدنية ضد من النجيليات وذللك في شهر مايو سنة ج . . r.

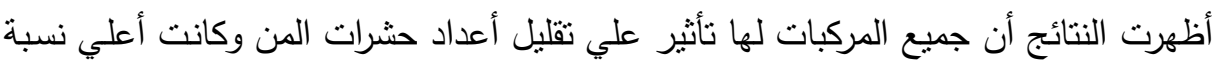

إبادة للحشرات لكل من مبيدات الملاثيون والريلدان والدلتان وكذلك السومثيون • حيث أعطت نسبة خفض

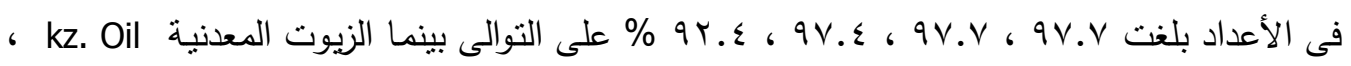

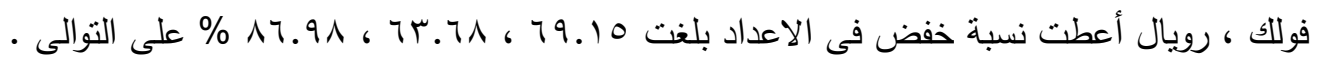

